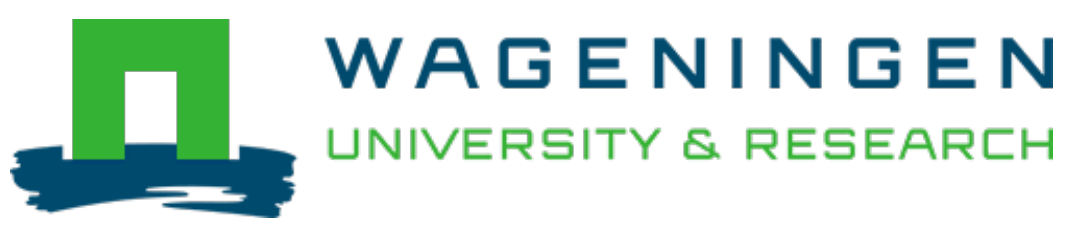

\title{
Solid-substrate fermentation of soybeans with Rhizopus spp. : Comparison of discontinuous rotation with stationary bed fermentation
}

\author{
Journal of Bioscience and Bioengineering \\ Han, B.; Kiers, J.L.; Nout, M.J.R. \\ https://doi.org/10.1016/s1389-1723(99)80203-5
}

This publication is made publicly available in the institutional repository of Wageningen University and Research, under the terms of article $25 \mathrm{fa}$ of the Dutch Copyright Act, also known as the Amendment Taverne. This has been done with explicit consent by the author.

Article 25 fa states that the author of a short scientific work funded either wholly or partially by Dutch public funds is entitled to make that work publicly available for no consideration following a reasonable period of time after the work was first published, provided that clear reference is made to the source of the first publication of the work.

This publication is distributed under The Association of Universities in the Netherlands (VSNU) 'Article $25 \mathrm{fa}$ implementation' project. In this project research outputs of researchers employed by Dutch Universities that comply with the legal requirements of Article $25 \mathrm{fa}$ of the Dutch Copyright Act are distributed online and free of cost or other barriers in institutional repositories. Research outputs are distributed six months after their first online publication in the original published version and with proper attribution to the source of the original publication.

You are permitted to download and use the publication for personal purposes. All rights remain with the author(s) and / or copyright owner(s) of this work. Any use of the publication or parts of it other than authorised under article $25 \mathrm{fa}$ of the Dutch Copyright act is prohibited. Wageningen University \& Research and the author(s) of this publication shall not be held responsible or liable for any damages resulting from your (re)use of this publication.

For questions regarding the public availability of this publication please contact openscience.library@wur.nl 


\title{
Solid-Substrate Fermentation of Soybeans with Rhizopus spp.: Comparison of Discontinuous Rotation with Stationary Bed Fermentation
}

\author{
BEIZHONG HAN, $§$ JEROEN L. KIERS, AND ROBERT M. J. NOUT* \\ Food Hygiene and Microbiology Group, Department of Food Technology and Nutritional Sciences, Agricultural \\ University, Bomenweg 2, $6703 \mathrm{HD}$ Wageningen, The Netherlands
}

Received 3 December 1998/Accepted 31 May 1999

\begin{abstract}
Tempe is a soybean food obtained by stationary solid-substrate fermentation using moulds (mainly Rhizopus spp.) as starter organism. Traditionally, tempe is fermented in static layer trays or wrapped packages. Due to heat and mass transfer limitations, gradients of temperature and gas atmosphere will result. Agitated fermentation can help to level heat and mass gradients, yielding better homogeneity. This type of process will not result in traditional tempe, but in individually fermented soybeans that could be processed into food ingredients. This report deals with the comparative effect of stationary versus agitated solid-substrate fermentation of soybeans on some chemical indices of substrate modification. For agitated solid-substrate fermentation, a $450-l$ size rotary-drum bioreactor was designed and constructed. Of two Rhizopus spp. tested, $R$. microsporus tolerated agitation quite well, as judged by changes of $\mathrm{pH}$, amino nitrogen, ammonia, and soluble dry matter. The other species, $\boldsymbol{R}$. oligosporus was strongly affected by agitation. This resulted in less pH increase (difference approx. 1.5 units), lower amino nitrogen levels (30-50\% of levels in static fermentation), and lower levels of watersoluble non-lipid dry matter (30-50\% of levels in static fermentation) with $R$. oligosporus agitated fermentation of soybeans controlled at 30 and $37^{\circ} \mathrm{C}$, compared to static fermentation at temperatures ranging between 25-35 and $30-40^{\circ} \mathrm{C}$, respectively.
\end{abstract}

[Key words: fungi Rhizopus, tempe, soya bean, agitated solid-substrate fermentation]

Solid-substrate fermentations (SSF) are generally characterized by the growth of microorganisms on waterinsoluble substrates in the presence of varying amounts of free water (1). In SSF, fungi grow best on undisturbed substrate, such as in traditional stationary layer trays. It is well-known that considerable quantities of $e . g$. traditional koji, oncom and tempe are produced using stationary beds, incubated at ambient temperatures and relative humidities. For purposes of upscaling for industrial mechanized processing the control of temperature, gas, and humidity gradients in static bed fermentations is difficult to perform (2).

Tempe, a traditional Indonesian food, is made by SSF. Fungi, particularly Rhizopus spp. are essential for tempe making, in which yellow-seeded soya beans are the most common and popular raw material (3).

Generally, tempe is produced in a bed or package by small-scale producers. When scaling up the production by increasing the fermentor size, problems can be expected owing to inadequatc dissipation of metabolic heat estimated from $2514 \mathrm{~kJ} \cdot \mathrm{kg}^{-1}$ (4) to $15.7 \mathrm{MJ} \cdot \mathrm{kg}^{-1}$ (5). Consequently, the temperature of tempe within a stationary bed or package may rise $10-16^{\circ} \mathrm{C}$ above that of the environment (6). The availability of $\mathrm{O}_{2}$ in a static layer is determined by diffusion, which in turn is determined by porosity, particle size and consistency of the substrate (7). Due to these limitations to mass transfer, $\mathrm{O}_{2}$ levels will decrease and $\mathrm{CO}_{2}$ will increase. In experimental stationary tempe beds incubated for $24 \mathrm{~h}$ at $35^{\circ} \mathrm{C}$ external temperature at a depth of $2 \mathrm{~cm}$ beneath the tempe sur-

\footnotetext{
* Corresponding author.

$\S$ Present address: College of Food Science and Engineering, China Agricultural University, Beijing 100083, China.
}

face, levels of temperature, $\mathrm{O}_{2}$ and $\mathrm{CO}_{2}$ reached $46^{\circ} \mathrm{C}$, $6 \%(\mathrm{v} / \mathrm{v})$ and $16 \%(\mathrm{v} / \mathrm{v})$, respectively. At $5.8 \mathrm{~cm}$ depth, these values were $39^{\circ} \mathrm{C}, 2 \%(\mathrm{v} / \mathrm{v})$ and $22 \%(\mathrm{v} / \mathrm{v})(6)$.

The Rotary-Drum Bioreactor (RDB) has potential for large-scale SSF and offers a means to mix the solid substrate, thus reducing heat and gas gradients. The use of RDB's has been reported for production of, for example, ethanol (8), enzymes (9), Koji, plant cells (10) and Rhizopus fermented soybeans (11). The kind of fermented soybean product produced in a RDB is not a traditional solid cake of tempe, but it consists of individually fermented soybeans. The latter can be easily processed into powdered food ingredients by drying and grinding. Some authors considered that agitation by rotation during a fermentation would have a negative effect on fungal growth and sporulation (12).

In contrast to research on submerged fermentation, so far, there are no reports on Rotary-Drum Bioreactors in pilot-scale solid-substrate fermentation. The purpose of this investigation is to test the behaviour of Rhizopus spp. in an agitated bioreactor. A comparison is made between fermentations of soybeans in the pilot-scale RDB and in traditional static packages of tempe.

\section{MATERIALS AND METHODS}

Microorganisms Rhizopus microsporus (LU573; $\mathrm{LU}=\mathrm{Landbouw}$ Universiteit Wageningen) and $R$. oligosporus (LU575) were grown for $7 \mathrm{~d}$ at $30^{\circ} \mathrm{C}$ and maintained at $4^{\circ} \mathrm{C}$ on malt extract agar (MEA, Oxoid CM 59, Basingstoke, UK) slants. Sporangiospore suspensions were obtained by scraping the sporangia off the agar and suspending them into sterile distilled water with $0.85 \%$ salt, $0.1 \%$ peptone and $0.05 \%$ Tween 80 . The 
viable count varied between $5 \times 10^{5}$ and $2 \times 10^{6}$ colonyforming-units (cfu) $\cdot \mathrm{ml}^{-1}$ when determined on Rose-Bengal Chloramphenicol Agar (Oxoid, CM 549). For each series a fresh sporangiospore suspension was prepared.

Bioreactor system Experiments were carried out in a Rotary-Drum Bioreactor (RDB) designed and manufactured by Department of Food Technology and Nutritional Sciences and the Central Workshop of the Agricultural University, Wageningen. A schematic side-view diagram of the bioreactor system is shown in Fig. 1. The system consists of a drum, rotary rollers, aeration tube, temperature control facilities and a system control box. The drum (made of stainless steel except for perspex front window) consisted of 3 sections that were interconnected by bolts and water-tight seals. The total length (i.e. using all sections as shown in Fig. 1 as $\mathrm{A}, \mathrm{B}$ and C) was $1.1 \mathrm{~m}$ and with an inner diameter of $0.7 \mathrm{~m}$, this resulted in a volume of $0.45 \mathrm{~m}^{3}$. The capacity for dry soybeans using 3 sections was $50-70 \mathrm{~kg}$ (corresponding to $100-140 \mathrm{~kg}$ cooked beans). The design allowed for flexibility, i.e. one or more of the three sections could be used. The drum was rotated by the rotary rollers connected with a variable speed drive motor. The rotation rate could be controlled from 1.5 to $4.0 \mathrm{rpm}$. The aeration tube allowed for supply of filtered air set at the rate of $2.01 \cdot \mathrm{min}^{-1}$. The temperature control apparatus included a Pt-100 sensor to measure product temperature in the drum, a thermostat-controlled water bath for warming, and three thermostat-controlled cold water sprays for cooling the drum. The water bath could be lowered (as low as the mark "lowest" in Fig. 1) to be out of contact with the drum during various manipulations of the drum. During fermentations, the water bath was raised to the mark "highest" in Fig. 1 to allow adequate immersion of the drum in the water to allow temperature control. Under steady fermentation conditions, the temperature could be controlled at setpoint $\pm 1^{\circ} \mathrm{C}$.

Fermentation process Yellow-seeded soybeans ( $G l y$ cine $\max$ ) were dehulled by dry abrasion and soaked overnight with accelerated acidification (13). Subsequently, the beans ( $\mathrm{pH}$ of soaking water $<4.5$ ) were rinsed gently with tap water and boiled for $20 \mathrm{~min}$, cooled and superficially dried (20-30 min at ambient temperature). The humidity of the beans was $60 \%$ (fresh weight basis) initially, decreasing to $57 \%$ at the end of the fermentation period.

The RDB was disinfected using 70\% alcohol before filling it with soybeans. After filling the drum with substrate and inoculation (using $1 \% \mathrm{~V} / \mathrm{m}$, i.e. $10 \mathrm{ml}$ sporangiospore suspension $\cdot \mathrm{kg}^{-1}$ substrate), the RDB was rotated for $30 \mathrm{~min}$ at $1.5 \mathrm{rpm}$ to achieve homogenous distribution of sporangiospores, and subsequently $450 \mathrm{~g}$ batches of inoculated beans were transferred into hard-plastic boxes $(205 \times 90 \times 45 \mathrm{~mm})$ with a regular pattern of $1 \mathrm{~mm}$ dia perforations, used for comparison of stationary bed fermentation with the agitated RDB. These boxes are identical to those used for commercial tempe production in the Netherlands.

Finally, the fermentation programme was set rotating for $30 \mathrm{~s}(1.5 \mathrm{rpm})$ followed by a stationary period of $3 \mathrm{~min}$, with air flow-rate $2.0 \mathrm{l} \cdot \mathrm{min}^{-1}$. The agitated SSF in the Rotary-Drum Bioreactor (RDB) and the static SSF in the plastic boxes were studied at 25,30 , and $37^{\circ} \mathrm{C}$. Due to accumulation of metabolic heat, temperatures in static SSF increased to about $12^{\circ} \mathrm{C}$ above that of the incubator (data not shown). Roughly, the temperatures of $30^{\circ} \mathrm{C}$ and $37^{\circ} \mathrm{C}$ as controlled in the RDB are comparable with the average temperatures evolving in static SSF incubated at $25^{\circ} \mathrm{C}$ and $30^{\circ} \mathrm{C}$, respectively. After one day of fermentation, a baffle was put in the drum to avoid lumping caused by mycelial growth. Samples were taken for analyses at regular intervals. Whereas our standard stationary bed process takes $44 \mathrm{~h}$ at $30^{\circ} \mathrm{C}$ incubation temperature, we continued (for experimental purposes) both processes up to $72 \mathrm{~h}$ in order to monitor changes of composition and texture.

pH and formol titration A 1-g sample (fresh weight) of fermented material was homogenized with $20 \mathrm{ml}$ demineralized water. The $\mathrm{pH}$ was measured in this suspension using a digital pH meter (WTW, type 525; Weilheim, Germany). To this suspension, $0.1 \mathrm{~mol} \cdot l^{-1}$ $\mathrm{NaOII}$ was added to a constant $\mathrm{pH} 8.5$ and then $5 \mathrm{ml}$ formaldehyde (37\%; Product no. 1.04003.1000, Merck, Darmstadt, Germany) was added. After 2 min the suspension was titrated using a semi-automated burette (SchottGeräte, type T81; Hofheim a. Ts., Germany) with 0.100 mol. $l^{-1} \mathrm{NaOH}$ to constant $\mathrm{pH} 8.5$ again $(\mathrm{pH}$ should be constant for $30 \mathrm{~s}$ ). Calculation: Free amino groups (mM. $\left.\mathrm{g}^{-1}\right)=0.1 \times V \cdot m^{-1}$; where $V$ is the volume of $0.100 \mathrm{~mol}$. $l^{-1} \mathrm{NaOH}$ used, and $m$ is the dry matter mass of a sample.

Determination of ammonia $\left(\mathbf{N H}_{3}\right)$ A $10 \mathrm{~g}$ sample (fresh weight) of fermented material was transferred into a Kjeldahl flask with $100 \mathrm{ml}$ demineralized water. The Kjeldahl flask was connected to a Kjeldahl distillation equipment (Gerhardt, type Vapodest 12, Bonn, Germany) to distil about $100 \mathrm{ml}$ of the water into a conical flask containing $25 \mathrm{ml} 4 \%$ boric acid and a few drops of mixed Kjeldahl indicator. Then the liquid in the conical flask was titrated with $0.100 \mathrm{~mol} \cdot l^{-1} \mathrm{HCl}$. Calculation: $\mathrm{NH}_{3}\left(\mathrm{mg} \cdot \mathrm{g}^{-1}\right)=0.1 \times V \times 17 \cdot \mathrm{m}^{-1}$; where $V$ is the volume of $\mathrm{HCl}$ used, and $m$ is the dry matter mass of a sample.

Crude lipid content The fermented samples were dried overnight in a cabinet drier $\left(50-60^{\circ} \mathrm{C}\right)$ and ground (Fritsch, type Pulverisette 14, Idar-Oberstein, Germany) to a fine powder $(\leq 1 \mathrm{~mm})$. A $25-\mathrm{g}$ sample was extracted with petroleum ether (boiling range $40-65^{\circ} \mathrm{C}$, Product no. 51473, Merck) in a Soxhlet extractor. After the petroleum ether was evaporated in an evaporator apparatus (Heidolph, type VV2000, Schwabach, Germany), the total crude lipid was quantified gravimetrically.

Solubility and protein A defatted sample was solubilized using distilled water in a flask with continuous stirring at $37^{\circ} \mathrm{C}$ for $30 \mathrm{~min}$. The suspensions were centrifuged at $1600 \times g$ at $4^{\circ} \mathrm{C}$ during $15 \mathrm{~min}$. The sediment was washed and centrifuged twice with distilled water. Subsequently the sediment was frozen and lyophilized. Finally, the dry matter content of the sediment and supernatant were determined gravimetrically. The nitrogen content of the supernatant was determined using the micro-Kjeldahl technique.

Microbiological analysis Lactic acid bacteria were enumerated in pour-plates of de Man, Rogosa and Sharpe (MRS) medium (Product no. 1.10661, Merck) to which $12 \mathrm{~g}$ agar and $1 \mathrm{~g}$ natamycin ("Delvocid", Gist-brocades, Delft, The Netherlands) were added per $l$, after incubation at $30^{\circ} \mathrm{C}$ for $3 \mathrm{~d}$.

Enterobacteriaceae were enumerated in pour-plates of Violet Red Bile Glucose (VRBG, Oxoid CM 485) medium with overlay after incubation at $30^{\circ} \mathrm{C}$ for $24-36 \mathrm{~h}$ (14). Initial confirmation was based on Gram stain and catalase activity.

Bacillus cereus were enumerated using spreading in- 


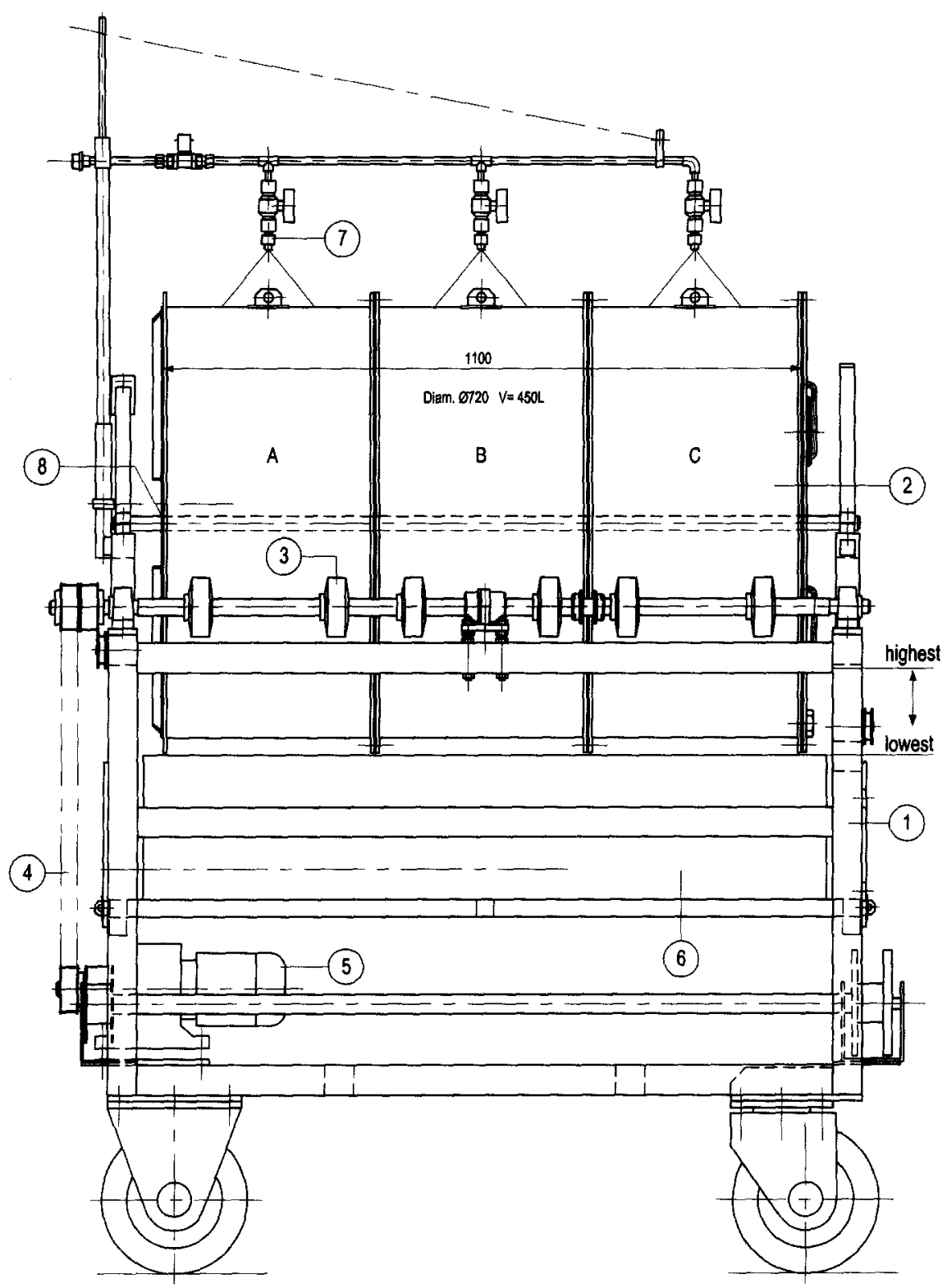

FIG. 1. Side view of Rotary-Drum Bioreactor (RDB). 1, Frame; 2, drum consisting of 3 sections (A, B, C); 3, roller; 4, drive belt; 5, variable speed electromotor; 6 , waterbath that can be raised to mark "highest" or lowered to mark "lowest" (shown here in its lowest position possible); 7 , cooling water spray; 8 , insertion point for product thermometer.

oculation on ready-poured plates of Cereus selective agar base acc. to Mossel (MYP) medium (Product no. 1.05267 , Merck) to which $100 \mathrm{~g}$ egg yolk and $1 \mathrm{~g}$ natamycin were added per $l$, after incubation at $30^{\circ} \mathrm{C}$ for $24-$ $36 \mathrm{~h}$.

Total aerobic mesophilic bacteria except for lactic acid bacteria were enumerated in pour-plates of Gelysate Peptone (Becton Dickinson, 4311870, Cockeysville MD, USA) to which $5 \mathrm{~g} \mathrm{NaCl}, 14 \mathrm{~g}$ agar and $1 \mathrm{~g}$ natamycin were added per $l(\mathrm{pH} 7.2 \pm 0.1)$, after incubation at $30^{\circ} \mathrm{C}$ for $3 \mathrm{~d}$.

Bacterial spores in pasteurised $\left(80^{\circ} \mathrm{C}, 10 \mathrm{~min}\right)$ samples were enumerated in pour-plates of Gelysate Peptone (Becton Dickinson, 4311870, USA) to which $5 \mathrm{~g} \mathrm{NaCl}$ and $14 \mathrm{~g}$ agar were added per $l(\mathrm{pH} 7.2 \pm 0.1)$, after incubation at $30^{\circ} \mathrm{C}$ for $3 \mathrm{~d}$.

\section{RESULTS}

pH changes Table 1 shows the $\mathrm{pH}$ changes during fermentation of soybeans with $R$. microsporus LU573 and $R$. oligosporus LU575 in the stationary beds at external incubation temperatures of $25^{\circ} \mathrm{C}$ and $30^{\circ} \mathrm{C}$ and reaching temperatures in the center of $37^{\circ} \mathrm{C}$ and $42^{\circ} \mathrm{C}$, respectively, and in the Rotary-Drum Bioreactor (RDB) controlled at 30 and $37^{\circ} \mathrm{C}\left( \pm 1^{\circ} \mathrm{C}\right)$. $\mathrm{pH}$ changes during the fermentation are the result of combined chemical modifications and of the buffering capacity of the product. The pH of samples from LU573 was higher than those from LU575, obtained under identical conditions. The $\mathrm{pH}$ in the stationary fermentations was higher than that in the RDB except for LU573 at $37^{\circ} \mathrm{C}$.

Proteolysis The formol titration gives an indication of the hydrolysis of proteins, by reacting with free 
TABLE 1. Chemical modification of soybeans during stationary and agitated solid-substrate fermentation with $R$. microsporus LU573 and $R$. oligosporus LU575

\begin{tabular}{|c|c|c|c|c|c|c|c|c|c|c|c|c|c|c|c|c|}
\hline \multicolumn{17}{|c|}{ R. microsporus LU573 } \\
\hline \multirow{2}{*}{$\begin{array}{l}\text { Time } \\
\text { (h) }\end{array}$} & \multicolumn{4}{|c|}{$\begin{array}{l}\text { Stationary bed } \\
25^{\circ} \mathrm{C} \rightarrow 37^{\circ} \mathrm{C}^{\mathrm{a}}\end{array}$} & \multicolumn{4}{|c|}{$\begin{array}{c}\text { Rotary-Drum Bioreactor } \\
30^{\circ} \pm 1^{\circ} \mathrm{C}^{\mathrm{b}}\end{array}$} & \multicolumn{4}{|c|}{$\begin{array}{l}\text { Stationary bed } \\
30^{\circ} \mathrm{C} \rightarrow 42^{\circ} \mathrm{C}\end{array}$} & \multicolumn{4}{|c|}{$\begin{array}{c}\text { Rotary-Drum Bioreactor } \\
37^{\circ} \pm 1^{\circ} \mathrm{C}\end{array}$} \\
\hline & $\mathrm{pH}$ & A.N. ${ }^{c}$ & $\mathrm{NH}_{3}{ }^{\mathrm{d}}$ & C.L. ${ }^{\mathrm{e}}$ & $\mathrm{pH}$ & A.N. & $\mathrm{NH}_{3}$ & C.L. & $\mathrm{pH}$ & A.N. & $\mathrm{NH}_{3}$ & C.L. & $\mathrm{pH}$ & A.N. & $\mathrm{NH}_{3}$ & C.L. \\
\hline 0 & 5.20 & 0.19 & 0.04 & 27.59 & 5.20 & 0.19 & 0.04 & 27.59 & 5.48 & 0.18 & 0.08 & 27.60 & 5.48 & 0.18 & 0.08 & 27.60 \\
\hline 24 & 5.43 & 0.25 & 0.04 & 27.45 & 5.42 & 0.23 & 0.04 & 27.41 & 6.37 & 0.38 & 0.16 & 28.72 & 5.40 & 0.23 & 0.00 & 27.93 \\
\hline 48 & 6.33 & 0.39 & 0.12 & 26.83 & 5.35 & 0.34 & 0.00 & 27.99 & 6.72 & 0.48 & 0.50 & 27.08 & 6.95 & 0.39 & 0.60 & 30.62 \\
\hline 72 & 6.47 & 0.51 & 0.32 & 25.10 & 5.01 & 0.53 & 0.00 & 29.10 & 6.32 & 0.84 & 0.88 & 25.75 & 6.21 & 0.76 & 0.65 & 32.20 \\
\hline \multicolumn{17}{|c|}{ R. oligosporus LU575 } \\
\hline \multirow{2}{*}{ Time } & \multicolumn{4}{|c|}{$\begin{array}{l}\text { Stationary bed } \\
25^{\circ} \mathrm{C} \rightarrow 37^{\circ} \mathrm{C}\end{array}$} & \multicolumn{4}{|c|}{$\begin{array}{l}\text { Rotary-Drum Bioreactor } \\
30^{\circ} \pm 1^{\circ} \mathrm{C}^{\mathrm{b}}\end{array}$} & \multicolumn{4}{|c|}{$\begin{array}{l}\text { Stationary bed } \\
30^{\circ} \mathrm{C} \rightarrow 42^{\circ} \mathrm{C}\end{array}$} & \multicolumn{4}{|c|}{$\begin{array}{c}\text { Rotary-Drum Bioreactor } \\
37^{\circ} \pm 1{ }^{\circ} \mathrm{C}\end{array}$} \\
\hline & $\mathrm{pH}$ & A.N. & $\mathrm{NH}_{3}{ }^{\mathrm{d}}$ & C.L. ${ }^{\mathrm{e}}$ & $\mathrm{pH}$ & A.N. & $\mathrm{NH}_{3}$ & C.I. & $\mathrm{pH}$ & A.N. & $\mathrm{NH}_{3}$ & C.L. & $\mathrm{pH}$ & A.N. & $\mathrm{NH}_{3}$ & C.L. \\
\hline 0 & 5.42 & 0.19 & 0.09 & 28.13 & 5.42 & 0.19 & 0.09 & 28.13 & 5.30 & 0.18 & 0.09 & 28.17 & 5.30 & 0.18 & 0.09 & 28.17 \\
\hline 24 & 6.05 & 0.32 & 0.34 & 27.96 & 5.05 & 0.21 & 0.05 & 28.06 & 6.10 & 0.37 & 0.48 & 29.35 & 5.35 & 0.19 & 0.25 & 28.71 \\
\hline 48 & 6.4 & 0.35 & 0.20 & 26.34 & 5.35 & 0.23 & 0.00 & 28.41 & 6.10 & 0.56 & 0.31 & 29.12 & 5.35 & 0.25 & 0.21 & 29.32 \\
\hline
\end{tabular}

a Temperature range during the fermentation, measured in the center of the bed ( $2.2 \mathrm{~cm}$ from bed surface).

b Setpoint and deviations throughout the fermentation, measured in the product.

c Amino nitrogen ( $\mathrm{mM} \cdot \mathrm{g}^{-1}$ fresh weight).

d Armmonia (ng $\cdot \mathrm{g}^{-1}$ fresh weight).

e Crude lipid (\% dry matter).

$\alpha$-amino groups. In Table 1 , data of amino nitrogen indicate that the fermentation products of LU573 generally have higher amino nitrogen contents than those of LU575. The lowest levels of amino nitrogen were observed in the RDB products of LU575. This suggests that proteolysis by LU 575 is more disturbed by agitation than that by LU573.

Ammonia Table 1 also shows the ammonia levels. The amount of ammonia in stationary beds is much higher than that in the RDB except for LU573 at $37^{\circ} \mathrm{C}$.

Crude lipid Interesting results were obtained for crude lipid as shown in Table 1 . The levels of crude lipid increased during the agitated fermentation process, whereas there was a decrease during the stationary fermentation.
Water-soluble non-lipid dry matter Table 2 shows that levels of water-soluble non-lipid dry matter (i.e. organic acids, sugars, and amino acids) in fermenting soybeans in the RDB decreased during the first day, and then increased gradually while those in the stationary beds increased during whole fermentation process. Especially with LU575 the RDB resulted in much lower solubility than the stationary fermentation at $72 \mathrm{~h}$.

Nitrogen content of water-soluble non-lipid dry matter Table 2 presents the shift of nitrogen levels as a result of substrate modification. Compared to the start (time $=0$ ) nitrogen levels increase in the soluble matter, in all fermentations. For both mould strains, the increases are strongest at the higher temperatures. For strain LU573, there are no big differences between nitrogen evolution

TABLE 2. Solubilization of soybeans during stationary and agitated solid-substrate fermentation with $R$. microsporus I.US73 and $R$. oligosporus T.U575

\begin{tabular}{|c|c|c|c|c|c|c|c|c|}
\hline \multicolumn{9}{|c|}{ R. microsporus LU573 } \\
\hline \multirow{2}{*}{$\begin{array}{l}\text { Time } \\
\text { (h) }\end{array}$} & \multicolumn{2}{|c|}{$\begin{array}{l}\text { Stationary bed } \\
25^{\circ} \mathrm{C} \rightarrow 37^{\circ} \mathrm{Ca}\end{array}$} & \multicolumn{2}{|c|}{$\begin{array}{c}\text { Rotary-Drum Bioreactor } \\
30^{\circ} \pm 1^{\circ} \mathrm{C}^{\mathrm{b}}\end{array}$} & \multicolumn{2}{|c|}{$\begin{array}{c}\text { Stationary bed } \\
30^{\circ} \mathrm{C} \rightarrow 42^{\circ} \mathrm{C} \\
\end{array}$} & \multicolumn{2}{|c|}{$\begin{array}{l}\text { Rotary-Drum Bioreactor } \\
37^{\circ} \pm 1^{\circ} \mathrm{C}\end{array}$} \\
\hline & Sol.c & N-Sol.d & Sol. & N-Sol. & Sol. & N-Sol. & Sol. & N-Sol. \\
\hline 0 & 19.5 & 2.2 & 19.5 & 2.2 & 18.9 & 1.3 & 18.9 & 1.3 \\
\hline 24 & 18.3 & 4.3 & 15.0 & 4.4 & 25.6 & 8.6 & 16.8 & 5.4 \\
\hline 48 & 25.8 & 7.7 & 18.4 & 7.1 & 29.0 & 9.2 & 22.0 & 9.9 \\
\hline 72 & 32.1 & 7.7 & 23.6 & 8.1 & 33.1 & 9.9 & 26.4 & 10.7 \\
\hline \multicolumn{9}{|c|}{ R. oligosporus LU575 } \\
\hline \multirow{2}{*}{ Time } & \multicolumn{2}{|c|}{$\begin{array}{l}\text { Stationary bed } \\
25^{\circ} \mathrm{C} \rightarrow 37^{\circ} \mathrm{C}^{\mathrm{a}}\end{array}$} & \multicolumn{2}{|c|}{$\begin{array}{c}\text { Rotary-Drum Bioreactor } \\
30^{\circ} \pm 1^{\circ} \mathrm{C}^{\mathrm{b}}\end{array}$} & \multicolumn{2}{|c|}{$\begin{array}{c}\text { Stationary bed } \\
30^{\circ} \mathrm{C} \rightarrow 42^{\circ} \mathrm{C}\end{array}$} & \multicolumn{2}{|c|}{$\begin{array}{c}\text { Rotary-Drum Bioreactor } \\
37^{\circ} \pm 1^{\circ} \mathrm{C}\end{array}$} \\
\hline & Sol.c & N-Sol.d & Sol. & N-Sol. & Sol. & N-Sol. & Sol. & N-Sol. \\
\hline 0 & 18.8 & 3.0 & 18.8 & 3.0 & 13.9 & 2.2 & 13.9 & 2.2 \\
\hline 24 & 26.1 & 6.5 & 10.7 & 3.0 & 21.1 & 6.2 & 12.0 & 3.6 \\
\hline 48 & 32.7 & 9.1 & 13.5 & 3.4 & 25.6 & 9.0 & 14.5 & 5.6 \\
\hline
\end{tabular}

a Temperature range during the fermentation, measured in the center of the bed $(2.2 \mathrm{~cm}$ from bed surface).

b Setpoint and deviations throughout the fermentation, measured in the product.

c Water-soluble non-lipid dry matter (\% dry weight).

${ }^{d}$ Nitrogen content of water-soluble non-lipid dry matter ( $\%$ dry weight). 
in stationary bed or RDB fermentations. With strain LU575, stationary fermentation resulted in nitrogen evolution comparable to strain LU573. However, in agitated fermentation, considerably less nitrogen was found in the soluble dry matter, especially at the $30^{\circ} \mathrm{C}$ controlled fermentation.

Microbiological composition There were no significant differences in microbial composition in the RDB and the stationary fermented samples at $0,24,48$ and $72 \mathrm{~h}$. The levels of lactic acid bacteria were $10^{9}-10^{10}$ cfu. $\mathrm{g}^{-1}$ after $24 \mathrm{~h}$. The levels of Enterobacteriaceae, bacterial spores and total aerobic mesophilic bacteria (except for LAB) were $10^{8}-10^{9}, 10-10^{2}$ and $10^{8}-10^{9} \mathrm{cfu} \cdot \mathrm{g}^{-1}$ after $48 \mathrm{~h}$, respectively. Bacillus cereus levels were below the detection limit $\left(<10 \mathrm{cfu} \cdot \mathrm{g}^{-1}\right)$. These numbers are quite normal for traditional tempe made under nonsterile conditions.

\section{DISCUSSION}

As it is difficult to quantify mycelial biomass in SSF on natural substrates such as soybeans, we selected several indirect parameters to determine the result of Rhizopus spp. growth and enzymic activity.

The change of $\mathrm{pH}$ during fermentation results from a combination of processes, including the release of ammonia and carbon dioxide, the assimilation of organic acids and the buffering capacity of soybeans. As a result of protein metabolism, normally a gradual increase of $\mathrm{pH}$, amino nitrogen, ammonia and water-solubility takes place (15) such as we observed in the stationary bed SSF. This was in contrast with the fermentation in the RDB. There are several possible reasons for this difference. First of all, the amount of enzymatically active biomass may be lower in the RDB although growth was very good as judged visually. Second, enzyme excretion may be impaired in the RDB for sensitive strains such as LU575. Nitrogen levels in water-soluble non-lipid dry matter (Table 2) suggest that LU575 has less proteolytic activity especially at $30^{\circ} \mathrm{C}$. Third, the mixing offers better availability of assimilable substrates to the mould during agitated fermentation. Fourth, the mixing and aeration in the RDB may decrease the levels of volatiles including ammonia.

In a previous investigation (16) it was observed that crude lipid levels decrease in stationary bed SSF of soybeans. This corresponds with our present data. The increase of crude lipid levels in the dry matter during the solid-substrate fermentation in the RDB could result from lipid synthesis, as well as from better assimilation of carbohydrate compounds. The latter phenomenon would be in line with the lower levels of water-soluble non-lipid dry matter in the RDB products.

The RDB enabled adequate aeration and temperature control. We also observed that the mould strains tested displayed different sensitivities to agitation. Further inves- tigations will be needed to understand the fundamental aspects of such sensitivity.

\section{ACKNOWLEDGMENTS}

The authors thank M. Schimmel and A.E. Sanders of the Central Workshop of the Agricultural University, Wageningen for construction engineering assistance. One of the authors (B. H.) was supported by the Sino-Dutch Exchange programme.

\section{REFERENCES}

1. Mitchell, D. A. and Lonsane, B. K.: Definition, characteristics and potential, p. 1-16. In Doelle, H. W. (ed.), Solid-substrate cultivation. Elsevier, Barking, England (1992).

2. Ryoo, D., Murphy, V. G., Karim, M. N., and Tengerdy, R. P.: Evaporative temperature and moisture control in a rocking reactor for solid substrate fermentation. Biotech. Techn., 5, 19-24 (1991).

3. Nout, M. J. R. and Rombouts, F. M.: Recent developments in tempe research. J. Appl. Bacteriol., 69, 609-633 (1990).

4. Aidoo, K. E., Hendry, R., and Wood, B. J. B.: Solid substrate fermentations. Adv. Appl. Microbiol., 28, 201-237 (1982).

5. Lonsane, B. K., Ghildyal, N.P., Budiatman, S., and Ramakrishna, S. V.: Engineering aspects of solid state fermentation. Enzyme Microb. Technol., 7, 258-265 (1985).

6. Rathbun, B. L. and Shuler, M. L.: Heat and mass transfer effects in static solid-substrate fermentations: design of fermentation chambers. Biotechnol. Bioeng., 25, 929-938 (1983).

7. Mitchell, D. A., Doelle, H. W., and Greenfield, P. H.: Improvement of growth of Rhizopus oligosporus on a model solid substrate. Biotechnol. Lett., 10, 497-502 (1988).

8. Kargi, F. and Curme, J. A.: Solid-state fermentation of sweet sorghum to ethanol in a rotary-drum fermentor. Biotechnol. Bioeng., 27, 1122-1125 (1985).

9. Silman, R. W.: Enzyme formation during solid-substrate fermentation in rotating vessels. Biotechnol. Bioeng., 22, 411-420 (1980).

10. Shibasaki, N., Hirose, K., Yonemoto, T., and Tadaki, T.: Suspension culture of nicotiana-tabacum cells in a rotary-drum bioreactor. J. Chem. Tech. Biotech., 53, 359-363 (1992).

11. de Rcu, J. C., Zwietering, M. H., Rombouts, F. M., and Nout, M.J. R.: Temperature control in solid substrate fermentation through discontinuous rotation. Appl. Microbiol. Biotechnol., 40, 261-265 (1993).

12. Cannel, E. and Moo-Young, M.: Solid-state fermentation systems. Process Biochem., 15, 2-7, 24-28 (1980).

13. Nout, M. J. R., de Dreu, M. A., Zuurbier, A. M., and Bonants-Van Laarhoven, T. M. G.: Ecology of controlled soyabean acidification for tempe manufacture. Food Microbiol., 4, 165-172 (1987)

14. Nout, M. J. R.: Ecology of accelerated natural lactic fermentation of sorghum-based infant food formulas. Int. J. Food Microbiol., 12, 217-224 (1991).

15. Steinkraus, K. H., Cullen, R. E., Pederson, C. S., Nellís, L. F., and Gavitt, B. K. (ed.): Indonesian tempe and related fermentations, p. 1-94. In Handbook of indigenous fermented foods. Marcel Dekker Inc., New York (1983).

16. de Reu, J. C., Ramdaras, D., Rombouts, F. M., and Nout, M. J. R.: Changes in soya bean lipids during tempe fermentation. Food Chem., 50, 171-175 (1994). 